\section{Rapid response of silicate weathering rates to climate change in the Himalaya}

\section{A. Dosseto ${ }^{1, *}$, N. Vigier ${ }^{2,3}$, R. Joannes-Boyau ${ }^{4}$}

\section{Moffat ${ }^{5,6}$, T. Singh ${ }^{7}$, P. Srivastava ${ }^{8}$}

\section{Abstract}

Chemical weathering of continental rocks plays a central role in regulating the carbon cycle and the Earth's climate (Walker et al., 1981; Berner et al., 1983), accounting for nearly half the consumption of atmospheric carbon dioxide globally (Beaulieu et al., 2012). However, the role of climate variability on chemical weathering is still strongly debated. Here we focus on the Himalayan range and use the lithium isotopic composition of clays in fluvial terraces to show a tight coupling between climate change and chemical weathering over the past $40 \mathrm{ka}$. Between 25 and $10 \mathrm{ka}$ ago, weathering rates decrease despite temperature increase and monsoon intensification. This suggests that at this timescale, temperature plays a secondary role compared to runoff and physical erosion, which inhibit chemical weathering by accelerating sediment transport and act as fundamental controls in determining the feedback between chemical weathering and atmospheric carbon dioxide.

Received 9 December 2014 | Accepted 23 January 2015 | Published 20 February 2015

\section{Letter}

It has long been recognised that the dissolution of minerals, chemical weathering, can act as a long-term (>1 Ma) feedback on the Earth's climate (Walker et al., 1981; Berner et al., 1983; Donnadieu et al., 2004). More recently, modelling studies have shown that the weathering engine can respond extremely rapidly

\footnotetext{
Wollongong Isotope Geochronology Laboratory, School of Earth \& Environmental Sciences, Universit of Wollongong, Wollongong, NSW, Australia

Corresponding author (email: tonyd@uow.edu.au)

Centre de Recherches Pétrographiques et Géochimiques, Vandoeuvre-les-Nancy, France

3. Now at Laboratoire d'Océanographie de Villefranche, Villefranche sur Mer, France

4. Southern Cross Geosciences, Southern Cross University, Lismore, NSW, Australia

Research School of Earth Sciences, The Australian National University, Canberra, ACT, Australia

Department of Archaeology, Flinders University, Bedford Park, South Australia

. CSIR Center for Mathematical Modelling and Computer Simulation, Bangalore, Karnataka, India

Wadia Institute of Himalayan Geology, Dehradun, Uttarakhand, India
}

$(<100 \mathrm{yr})$ to climate change and may act as a key component in the atmospheric $\mathrm{CO}_{2}$ level short-term regulation (Beaulieu et al., 2012). However, the relative role of climatic parameters on chemical weathering is still debated. Model simulations and geochemical studies of river-born material highlight either a temperature dependence (Walker et al., 1981), where warming promotes chemical weathering, or a predominance of other parameters like mechanical erosion (Raymo and Ruddiman, 1992; Gaillardet et al., 1999; Riebe et al., 2001; Donnadieu et al., 2004) and vegetation (Bayon et al., 2012). To address this question, another possible approach consists in investigating past continental environments through the study of marine or floodplain deposits. However, because in large river systems sediment transport and storage operates over $>10^{4} \mathrm{yr}$ timescales (Granet et al., 2010), a significant time lag may exist between the time when sediments acquired their geochemical characteristics, reflecting palaeoenvironmental conditions, and their final deposition.

Here we use the lithium ( $\mathrm{Li}$ ) isotopic composition of clays from sedimentary records in Himalayan basins to determine how chemical weathering intensity has varied over the past $40 \mathrm{ka}$ and particularly since the Last Glacial Maximum (locally older than $24 \mathrm{ka}$; Owen et al., 2002). In order to minimise the time lag between source and deposit locations, we have focused on alluvial deposits located in the headwater areas of the Ganges and Yamuna Rivers.

While little isotope fractionation occurs during mineral dissolution clay formation induces strong fractionations at low temperature, whereby ${ }^{6} \mathrm{Li}$ is preferentially incorporated into clays compared to ${ }^{7} \mathrm{Li}$, resulting in a strong enrichment of ${ }^{7} \mathrm{Li}$ in waters (Burton and Vigier, 2011). Thus, it has been shown that the $\delta^{7} \mathrm{Li}$ composition of natural waters can be used as a proxy for chemical weathering rates at the catchment scale, since the heaviest $\delta^{7} \mathrm{Li}$ compositions in water are associated with the areas characterised by low catchment-wide silicate weathering rates (Fig. 1). Several studies have also shown that the $\delta^{7} \mathrm{Li}$ composition of solid weathering products (i.e. soils, river sediments) is sensitive to chemical weathering conditions, where lower $\delta^{7} \mathrm{Li}$ values reflect more intensive leaching (Burton and Vigier, 2011).

To evaluate the reliability of the records studied, we investigated three different regions of the Himalaya and its piedmont in India: the upper Yamuna River basin, the Alaknanda River basin and the Donga Fan (Fig. S-1). Depositional ages for the alluvial deposits reported here were previously constrained by optically-stimulated luminescence (OSL) dating and range from 9 to $41 \mathrm{ka}$ (Singh et al., 2001; Ray and Srivastava, 2010). Both bulk sediments and clay-sized fractions were analysed for Li isotopes. In bulk sediments, mineralogical abundances and $\mathrm{Sr}$ isotopes were also measured (see Supplementary Information).

The $\delta^{7} \mathrm{Li}$ compositions of bulk sediments vary between -1.54 and $+1.98 \%$ while clay-sized fractions show a much broader range. Most samples show low $\delta^{7} \mathrm{Li}$ values best explained by significant ${ }^{6} \mathrm{Li}$ enrichment during clay formation (Burton and Vigier, 2011). The $\delta^{7} \mathrm{Li}$ values in bulk samples and clay-sized fractions evolve consistently as a function of time: both decrease between 35 and $25 \mathrm{ka}$, 


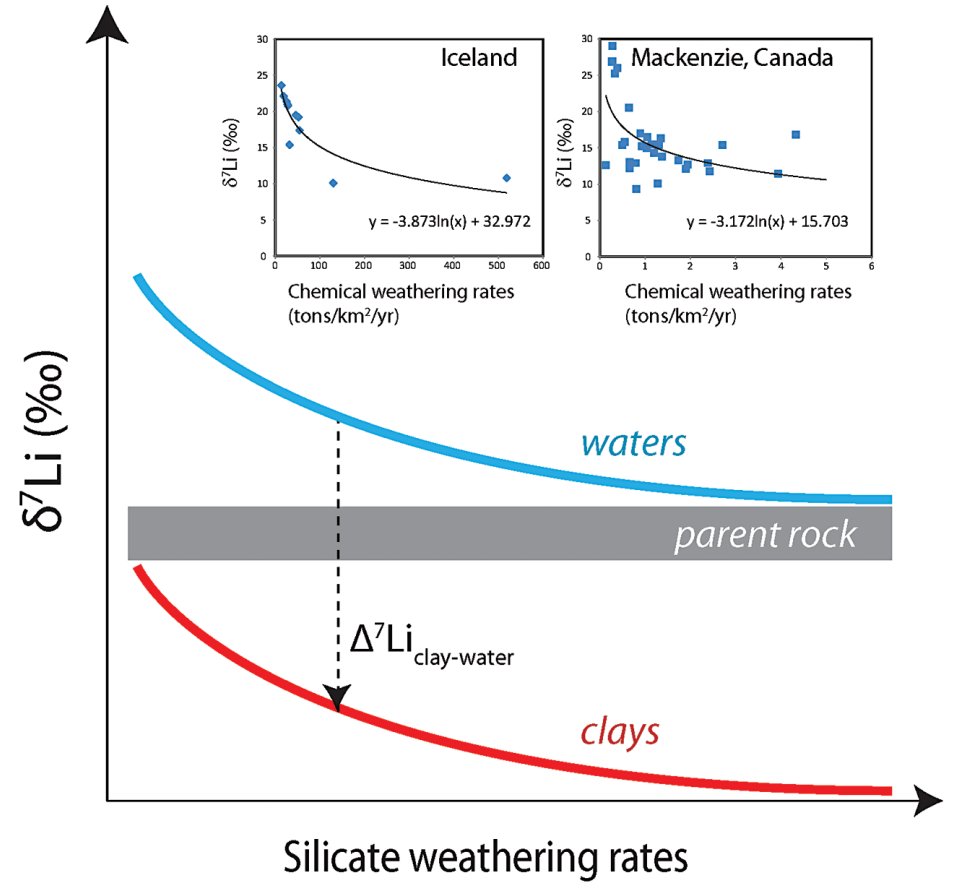

Figure 1 Relationship between $\delta^{7} \mathrm{Li}$ values of waters and clay minerals, and silicate weathering rates - estimated independently $\left(\delta^{7} \mathrm{Li}=\left[\left({ }^{7} \mathrm{Li} /{ }^{6} \mathrm{Li}\right) /\left({ }^{7} \mathrm{Li} /{ }^{6} \mathrm{Li}\right)\right.\right.$ L-SVEC -1$\left.] \times 1000\right)$ where $\mathrm{L}-\mathrm{SVEC}$ is the standard). Most published studies highlight an inverse correlation between water $\delta^{7} \mathrm{Li}$ and weathering rates at the watershed scale. For a given $\mathrm{Li}$ isotope fractionation between clay and rates. Thus, low $\delta^{\nabla} \perp i$ values are indicative of fast weathering rates. Insets show data for river waters from the Macken of Iceland (Vigier et al. 2009). The curves in the insets show a logarithmic regression through the data.

then increase between 25 and 10 ka (Fig. 2 and Fig. S-4). Several hypotheses can potentially account for the observed $\delta^{7} \mathrm{Li}$ variations: (i) change of sediment sources, (ii) changes in chemical weathering conditions (prior to deposition) and (iii) post-depositional alteration within the terraces.

Change of sediment sources is unlikely to control the $\delta^{7} \mathrm{Li}$ composition of clay-sized fractions because (i) the mineralogy of the clay-sized fraction is dominated by secondary clays that account for most of the Li budget; (ii) most igneous, metamorphic and sedimentary rocks have $\delta^{7} \mathrm{Li} \geq 0 \%$ o (Table S-3 and references therein). Thus, clay $\delta^{7} \mathrm{Li}$ compositions as low as $-4 \%$ o between 30 and $25 \mathrm{ka}$ are significantly lower than both the average values for unweathered continental rocks and published values for Himalayan river bedload sediments (Kisakürek et al., 2005).

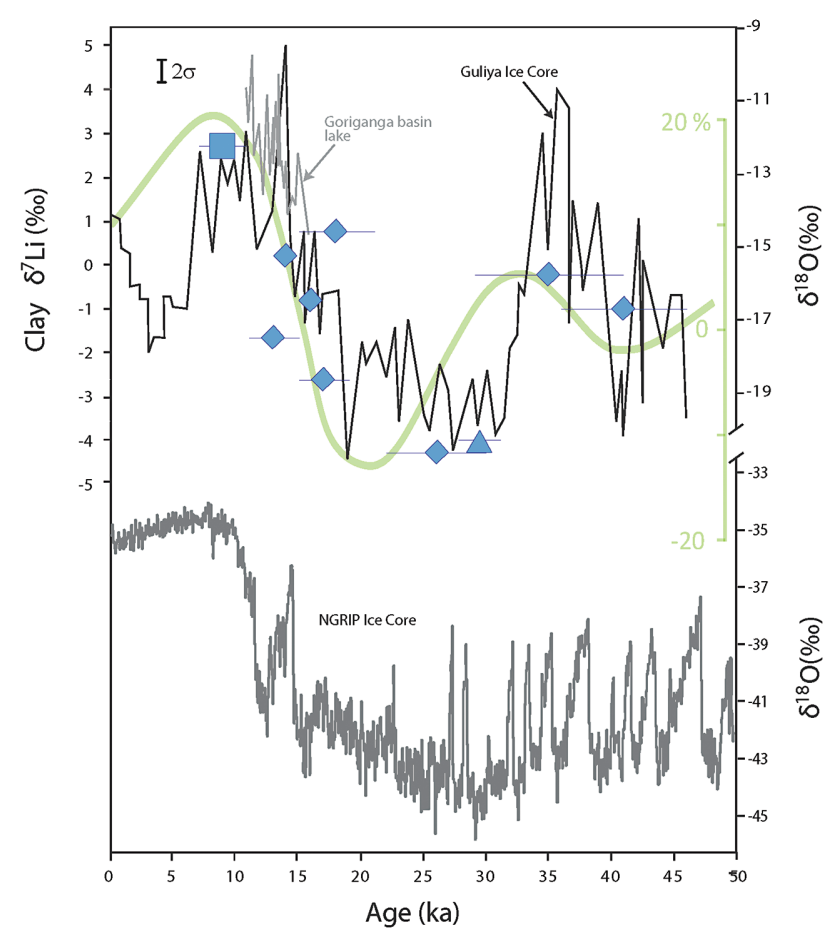

Figure 2 Clay $\delta^{7} L i$ as a function of terrace deposition ages (square: Yamuna, triangle: Donga Figure 2 Clay $\delta^{\prime} \mathrm{Li}$ as a function of terrace deposition ages (square: Yamuna, triangle: Donga
Fan and diamonds: Alaknanda). The vertical bracket in the top left corner shows the external Indian Monsoon for South Asia (green axis graduated from -20 to $20 \%$. Sanyal and Sinha 2010 and references therein). The black curve represents the $\delta^{18} \mathrm{O}$. 20 record from the Guliya ice core on the Qinghai-Tibetan Plateau (right $y$-axis) (Thompson et al. 1997). The grey curve is the $\delta^{18} \mathrm{O}$. east of the study area (Beukema et al. 2011). Records from the Guliya ice core and the lacustrine sediments from the Gorigang basin show that relative changes in climatic conditions were consistent on both sides of the divide, at least for this period. Comparison with a global palaeo-climatic record is illustrated with the grey curve, showing the NGRIP ice core $\delta^{18} \mathrm{O}$ record

from Greenland for the same period (North Greenland Ice Core Project members, 2004).

After deposition, weathering of alluvial sediments could bias the Li isotope composition of sediments and clays. However, several lines of evidence argue against this: (i) post-depositional alteration is expected to mainly affect the "exchangeable" Li. Experimental work has shown that Li is quickly incorporated into clay octahedral sites. It then remains into these sites even after intensive (hydrothermal) treatment (Vigier et al., 2008). As a consequence, low-temperature water percolating through deposited sediment will principally, and quickly, react with exchangeable cations but not with $\mathrm{Li}^{+}$ions in octahedral sites. Thus, to 
ensure that measured $\mathrm{Li}$ isotope compositions were not overprinted by any $\mathrm{Li}$ water-clay exchange during post-depositional alteration, the exchangeable Li was systematically removed during sample preparation (Supplementary Information) (ii) There is no simple relationship between $\delta^{7} \mathrm{Li}$ compositions and sampling depth (Fig. S-5). In fact, superficial alteration was carefully avoided by collecting samples located at significant depths ( $9 \mathrm{~m}$ on average), whereas soil development (if any) was restricted to the upper $2 \mathrm{~m}$. Furthermore, all selected samples derive from undisturbed stratigraphic sections, with no sign of post-depositional alteration (Supplementary Information). (iii) If post-depositional alteration was significant, $\delta^{7} \mathrm{Li}$ would be expected to correlate with depositional age. However, this is not observed as the oldest deposits (37-41 ka) display $\delta^{7} \mathrm{Li}$ values that are similar to more recent sediments (Table S-1). Alternatively, the lack of relationship with depositional age could reflect complex lateral fluid flow. However, this water-sediment interaction would also only affect the exchangeable $\mathrm{Li}$, which was removed as indicated above. (iv) Several samples with similar depositional ages but from different regions show consistent $\delta^{7} \mathrm{Li}$ values as a function of age (Table S-1).

As a first approximation, since $\mathrm{Li}$ isotope fractionation during clay formation is temperature-dependent (Vigier et al., 2008), $\delta^{7} \mathrm{Li}$ variations in clays could potentially reflect mean temperature change since the Last Glacial Maximum (LGM). Warming since the LGM has been estimated between 4 and $7{ }^{\circ} \mathrm{C}$ (Farrera et al., 1999). Experimental data indicate that this temperature increase could induce an increase in $\delta^{7} \mathrm{Li}$ between 0.5 and $0.9 \%$ in the solid (Vigier et al. 2008). This is well below the extent of the increase in $\delta^{7} \mathrm{Li}$ observed in clay-sized fractions (of $\sim 7 \%$ o). Thus, temperature variations alone cannot account for the observed range in $\delta^{7} \mathrm{Li}$ values.

Several studies have shown that the $\delta^{7} \mathrm{Li}$ values measured in river waters and soils decrease with increasing chemical weathering rates at the scale of the watershed or the soil profile (Fig. 1; Kisakürek et al., 2005; Vigier et al., 2009; Millot et al., 2010). In addition, the low $\delta^{7} \mathrm{Li}$ values of clay-sized fractions support an enrichment in ${ }^{6} \mathrm{Li}$ in secondary phases during chemical weathering (Kisakürek et al., 2005). Consequently, variations in $\delta^{7} \mathrm{Li}$ are best explained by changes in weathering conditions over the past $40 \mathrm{ka}$. In this case, the decrease towards low $\delta^{7} \mathrm{Li}$ compositions between 35 and $25 \mathrm{ka}$ indicates an increase in weathering rates over this period of time. The following increase in $\delta^{7} \mathrm{Li}$ between 25 and $10 \mathrm{ka}$ then suggests that weathering rates have decreased since the end of the LGM. An intimate link between climate and weathering in this region appears when comparing clay $\delta^{7} \mathrm{Li}$ and the oxygen isotope compositions recorded by the Guliya ice core from the Qinghai-Tibetan Plateau (Fig. 2; Thompson et al., 1997). This oxygen isotope record is consistent with an intensification of the monsoon between 25 and $10 \mathrm{ka}$ ago, as suggested by most studies (Goodbred and Kuehl, 2000; Sanyal and Sinha, 2010; Beukema et al., 2011). Consequently, the co-variation between $\delta^{7} \mathrm{Li}$ and $\delta^{18} \mathrm{O}$ values indicates a synchronicity between changes in chemical weathering rates and monsoon intensity.
The strontium ( $\mathrm{Sr}$ ) isotope composition of bulk sediments also shows systematic variations with time, similar to that of $\delta^{7} \mathrm{Li}$ (Fig. 3). Strontium isotopes have been used to study changes in the provenance of sediments, on the basis of different ${ }^{87} \mathrm{Sr} /{ }^{86} \mathrm{Sr}$ ratios in the source rocks found in the catchment (Galy and France-Lanord, 1999). Average ${ }^{87} \mathrm{Sr} /{ }^{86} \mathrm{Sr}$ ratios for the Higher Himalaya Crystallines (HHC) and the Lesser Himalayas (LH) are significantly different: $0.76 \pm 0.03$ and $0.85 \pm 0.09$, respectively (Rahaman et al., 2009). Thus, the observed increase in ${ }^{87} \mathrm{Sr} /{ }^{86} \mathrm{Sr}$ between 25 and $10 \mathrm{ka}$ could be interpreted as an increasing contribution of sediments from the LH. However, as the monsoon intensified between 25 and $10 \mathrm{ka}$ ago (Sanyal and Sinha, 2010), moisture penetrated further north, promoting erosion in the $\mathrm{HHC}$, as demonstrated for the Sutlej River (Bookhagen et al., 2005). More sediments from the HHC would have resulted in a decrease of sediment ${ }^{87} \mathrm{Sr} /{ }^{86} \mathrm{Sr}$ ratios, at odds with the data presented here (Fig. 3). Furthermore, if provenance controlled the ${ }^{87} \mathrm{Sr} /{ }^{86} \mathrm{Sr}$ ratio, sediments of the Donga Fan should show high values (because they only drain the LH) and the Sr isotopic composition of the Alaknanda River sediments should increase downstream (as more sediments are derived from the LH). However, our data show the opposite trend (Fig. S-6).

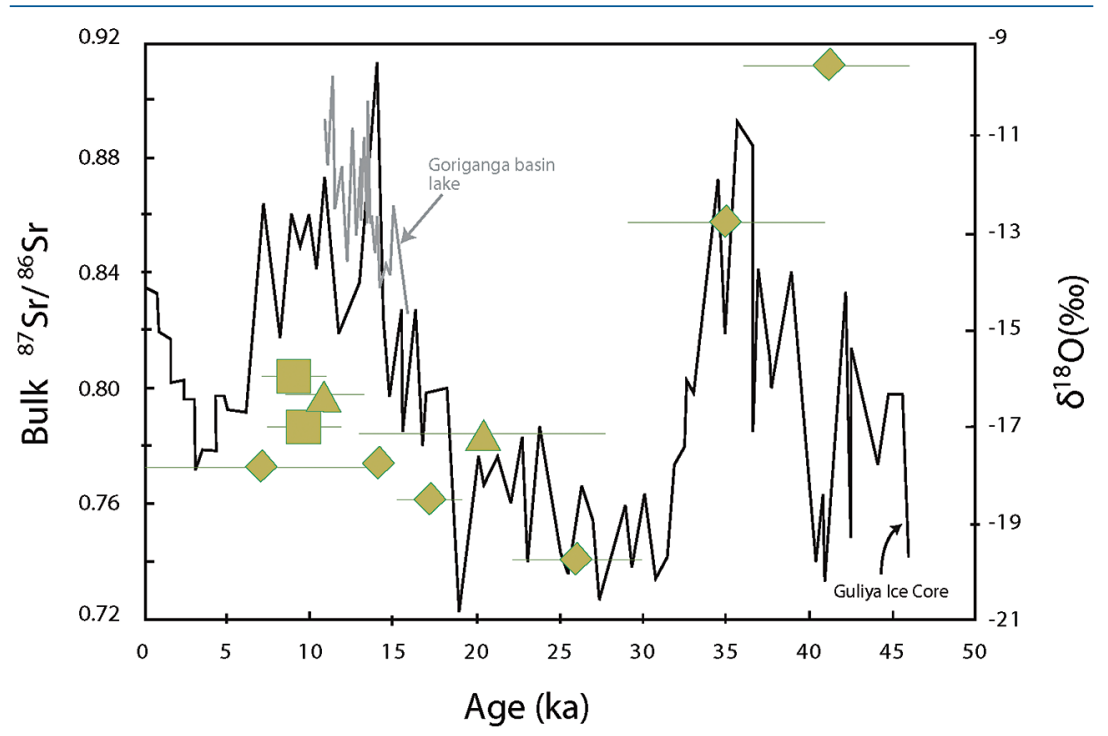

Figure $3{ }^{87} \mathrm{Sr} /{ }^{86} \mathrm{Sr}$ ratios of bulk sediments as a function of terrace deposition ages (same symbols as in Fig. 2). The error on ${ }^{87} \mathrm{Sr} /{ }^{86} \mathrm{Sr}$ ratios is smaller than the symbol size. The black curve represents the $\delta^{18} \mathrm{O}_{\text {smow }}$ record from the Guliya ice core on the Qinghai-Tibetan Plateau (right $y$-axis) (Thompson et al., 1997 ). The grey curve is the $\delta^{18} \mathrm{O}_{\text {VPDB }}$ record from lacustrine
sediments in the Goriganga basin (right y-axis) (Beukema et al., 2011). 
Alternatively, variations in Sr isotopes can reflect changes in weathering conditions since minerals with different susceptibility to weathering display different ${ }^{87} \mathrm{Sr} /{ }^{86} \mathrm{Sr}$ ratios (Blum et al., 1993; Colin et al., 1999). For instance, Blum et al. (1993) have highlighted a significant dissolution of high ${ }^{87} \mathrm{Sr} /{ }^{86} \mathrm{Sr}$ phases in glaciated areas. Bulk sediments from the three regions studied show a correlation between their ${ }^{87} \mathrm{Sr} /{ }^{86} \mathrm{Sr}$ and mineralogical content, such as micas and orthoclase (Fig. S-7). This suggests that the relative dissolution of primary minerals controls the ${ }^{87} \mathrm{Sr} /{ }^{86} \mathrm{Sr}$ of the bulk sediment, rather than sediment provenance. Thus, the minimum in ${ }^{87} \mathrm{Sr} /{ }^{86} \mathrm{Sr}$ values associated with the lowest $\delta^{7} \mathrm{Li}$ values at $25 \mathrm{ka}$ is consistent with more intense weathering conditions, when $\delta^{18} \mathrm{O}$ values of local and NGRIP ice cores both indicate cold conditions.

Taken together, Li and Sr isotope systematics suggest that chemical weathering conditions in the Himalayan range have been significantly affected by climatic variations between 40 and $10 \mathrm{ka}$. Moreover, synchronous variations (within errors) between $\delta^{7} \mathrm{Li}$ and $\delta^{18} \mathrm{O}$ values suggest that the response of transport and storage of weathering products to climate change was rapid $(<$ a few thousand years). Our data indicate that chemical weathering rates significantly decreased between 25 and $10 \mathrm{ka}$. It is possible to estimate the corresponding magnitude of changes in silicate weathering rates using a constant clay-water fractionation: an increase of clay $\delta^{7} \mathrm{Li}$ from $-4 \%$ to $+3 \%$ corresponds to an increase of water $\delta^{7} \mathrm{Li}$ of $7 \%$ o for the considered period. As a first approximation, using the relationship between water $\delta^{7} \mathrm{Li}$ and weathering rates (Vigier et al., 2009; Millot et al., 2010), this change in $\delta^{7} \mathrm{Li}_{\text {water }}$ would translate to a decrease in silicate weathering rates by an order of magnitude (using the regression for the Mackenzie data, Fig. 1 and $\Delta^{7} \mathrm{Li}_{\text {clay-water }}=-17 \%$; Vigier et al., 2008).

This decrease in chemical weathering rates coeval with global warming since the end of the LGM runs counter to the expectation that chemical weathering is promoted by warmer and wetter conditions (Walker et al., 1981). This result highlights runoff and physical erosion as major controls on chemical weathering in the Himalayan region for the last $25 \mathrm{ka}$, climate warming playing a secondary role at this timescale. It has been proposed that a significant increase in erosion rates accompanied monsoon intensification in the Himalaya since the end of the LGM, mainly via increased runoff (Bookhagen et al., 2005; Clift et al., 2008) and its effect on landsliding and fluvial incision. The resulting increased sediment transport is likely to have reduced the average residence time of soils and sediments within the basins, which in turn would have limited chemical weathering. In contrast, at the LGM, the observation of more intense weathering could be explained by the high surface area of the regolith produced by glacial erosion, promoting mineral dissolution despite colder conditions.

Recently, Beaulieu et al. (2012) have shown that at the decadal/centennial scale, the chemical weathering response, dominated by carbonate weathering, is sensitive to both runoff and temperature. Distinguishing between the two factors can be challenging, since they are often linked to each other (Labat et al., 2004).
Here, our results show that at the millennial scale, silicate chemical weathering rates in the Himalayan range are mainly driven by runoff and physical erosion, while temperature plays a secondary role.

\section{Acknowledgements}

We would like to thank Yogesh Ray, P.O. Suresh, David Fink, Paul Hesse, JanHendrik May and Oliver Korup for their assistance in the field. The Director of the Wadia Institute of Himalayan Geology is acknowledged for extending logistic support. Greg Ravizza, Ken Rubin, Doug Pyle, Chris Russo and Denys Vonderhaar at University of Hawai'i at Manoa, Aimeryc Schumacher at CRPG, and Paul Carr, Brian Jones, Venera Espanon, Jose Abrantes at University of Wollongong are thanked for their assistance with the analytical work. We would also like to thank John D. Jansen, Pete Burnard, Helen McGregor, Jan-Hendrik May, Tim Cohen, Allen Nutman and Colin Murray-Wallace for their comments on the manuscript. Finally, we would like to acknowledge Christian France-Lanord, Albert Galy, Marteen Lupker, Doug Burbank, François Chabaux, Cliff Riebe, Josh West and Niels Hovius for helpful discussions. A. Dosseto acknowledges an Australian Research Council Future Fellowship FT0990447 and a University of Wollongong URC Small Grant.

Editor: Eric H. Oelkers

\section{Additional Information}

Supplementary Information accompanies this letter at www.geochemicalperspectivesletters.org/article1502

Reprints and permission information is available online at http://www. geochemicalperspectivesletters.org/copyright-and-permissions

Cite this letter as: Dosseto, A., Vigier, N., Joannes-Boyau, R., Moffat, I., Singh, T., Srivastava, P. (2015) Rapid response of silicate weathering rates to climate change in the Himalaya. Geochem. Persp. Let. 1, 10-19.

\section{References}

Bayon, G., Dennielou, B., Etoubleau, J., Ponzevera, E., Toucanne, S., Bermell, S. (2012) Intensifying Weathering and Land Use in Iron Age Central Africa. Science 335, 1219-1222.

Beaulieu, E., Godderis, Y., Donnadieu, Y., Labat, D., Roelandt, C. (2012) High sensitivity of the continental-weathering carbon dioxide sink to future climate change. Nature Climate Change 2, 346-349. 
BERnER, R.A., LASSAGA, A.C., GARRelS, R.M. (1983) The carbone-silicate geochemical cycle and its effect on atmospheric carbon dioxide over the past 100 million years. American Journal of Science 283, 641-683.

Beukema, S.P., Krishnamurthy, R.V., JuYaL, N., Basavaiah, N., SinghVI, A.K. (2011) Monsoon variability and chemical weathering during the late Pleistocene in the Goriganga basin, higher central Himalaya, India. Quaternary Research 75, 597-604

BLUM, J.D., EREL, Y., BROWN, K. (1993) ${ }^{87} \mathrm{Sr} /{ }^{86} \mathrm{Sr}$ ratios of Sierra Nevada stream waters: Implications for relative mineral weathering rates. Geochimica et Cosmochimica Acta 57, 5019-5025.

BOOKHAgen, B., THIEDE, R.C., StRECKER, M.R. (2005) Late Quaternary intensified monsoon phases control landscape evolution in the northwest Himalaya. Geology 33, 149-152.

BurTON, K.W., VIGIER, N. (2011) Lithium Isotopes as Tracers in Marine and Terrestrial Environments. In: Baskaran, M. (Eds.) Handbook of Environmental Isotope Geochemistry. Springer Berlin Heidelberg, 41-59.

Clift, P.D., Giosan, L., BIusztajn, J., Campbell, I.H., Allen, C., Pringle, M., Tabrez, A.R., Danish, M., Rabbani, M.M., Alizai, A., Carter, A., Lueckge, A. (2008) Holocene erosion of the Lesser Himalaya triggered by intensified summer monsoon. Geology 36, 79-82.

Colin, C., Turpin, L., BertauX, J., Desprairies, A., Kissel, C. (1999) Erosional history of the Himalayan and Burman ranges during the last two glacial-interglacial cycles. Earth and Planetary Science Letters 171, 647-660.

Donnadieu, Y., Godderis, Y., Ramstein, G., Nedelec, A., Meert, J. (2004) A 'snowball Earth' climate triggered by continental break-up through changes in runoff. Nature 428, 303-306.

Farrera, I., Harrison, S.P., Prentice, I.C., Ramstein, G., Guiot, J., Bartlein, P.J., Bonnefille, R., Bush, M., Cramer, W., von Grafenstein, U., Holmgren, K., Hooghiemstra, H., Hope, G., Jolly, D., Lauritzen, S.E., Ono, Y., Pinot, S., Stute, M., Yu, G (1999) Tropical climates at the Last Glacial Maximum: a new synthesis of terrestrial palaeoclimate data. I. Vegetation, lake-levels and geochemistry. Climate Dynamics 15, 823-856.

Gaillardet, J., DupRE, B., AllĖGRE, C.J. (1999) Geochemistry of large river suspended sediments: Silicate weathering or recycling tracer? Geochimica et Cosmochimica Acta 63, 4037-4051.

GALY, A., FranCE-LANORD, C. (1999) Weathering processes in the Ganges-Brahmaputra basin and the riverine alkalinity budget. Chemical Geology 159, 31-60.

GoodBRED, S.J., KUEHL, S.A. (2000) Enormous Ganges-Brahmaputra sediment dischange during strengthened early Holocene monsoon. Geology 28, 1083-1086.

Granet, M., Chabaux, F., Stille, P., Dosseto, A., France-Lanord, C., Blaes, E. (2010) U-series disequilibria in suspended river sediments and implication for sediment transfer time in alluvial plains: The case of the Himalayan rivers. Geochimica et Cosmochimica Acta 74, 2851-2865.

KISAKÜREK, B., JAMES, R.H., HARRIS, N.B.W. (2005) Li and $\delta^{7} \mathrm{Li}$ in Himalayan rivers: Proxies for silicate weathering? Earth and Planetary Science Letters 237, 387-401.

LABAT, D., GodDÉRIS, Y., PROBST, J.L., GUYOT, J.L. (2004) Evidence for global runoff increase related to climate warming. Advances in Water Resources 27, 631-642.

Millot, R., VigieR, N., Gaillardet, J. (2010) Behaviour of lithium and its isotopes during weath ering in the Mackenzie Basin, Canada. Geochimica et Cosmochimica Acta 74, 3897-3912.

North Greenland Ice Core Project Members (2004) High-resolution record of Northern Hemisphere climate extending into the last interglacial period. Nature 431, 147-151.

OWEN, L.A., FINKEL, R.C., CAFFEE, M.W. (2002) A note on the extent of glaciation throughout the Himalaya during the global Last Glacial Maximum. Quaternary Science Reviews 21, 147-157.

Rahaman, W., Singh, S.K., SinHa, R., TANDON, S.K. (2009) Climate control on erosion distribution over the Himalaya during the past $\sim 100$ ka. Geology 37, 559-562.
RAY, Y., SRIVASTAVA, P. (2010) Widespread aggradation in the mountainous catchment of the Alaknanda-Ganga River System: timescales and implications to Hinterland-foreland relaAlaknanda-Ganga River System: timescales and im
tionships. Quaternary Science Reviews 29, 2238-2260.

Raymo, M.E., Ruddiman, W.F. (1992) Tectonic Forcing of Late Cenozoic Climate. Nature 359, $117-122$.

Riebe, C.S., Kirchner, J.W., Granger, D.E., Finkel, R.C. (2001) Strong tectonic and weak climatic control of long-term chemical weathering rates. Geology 29, 511-514.

SANYAL, P., SinHA, R. (2010) Evolution of the Indian summer monsoon: synthesis of continental records. Geological Society, London, Special Publications 342, 153-183.

Singh, A.K., Parkash, B., Mohindra, R., Thomas, J.V., SinghVI, A.K. (2001) Quaternary alluvial fan sedimentation in the Dehradun Valley Piggyback Basin, NW Himalaya: tectonic and palaeoclimatic implications. Basin Research 13, 449-471.

Thompson, L.G., YaO, T., Davis, M.E., Henderson, K.A., Mosley-Thompson, E., Lin, P.-N., BeER, J., Synal, H.-A., Cole-DAI, J., BolZAn, J.F. (1997) Tropical Climate Instability: The Last Glacial Cycle from a Qinghai-Tibetan Ice Core. Science 276, 1821-1825.

Vigier, N., Decarreau, A., Millot, R., Carignan, J., Petit, S., France-Lanord, C. (2008) Quantifying $\mathrm{Li}$ isotope fractionation during smectite formation and implications for the $\mathrm{Li}$ cycle. Geochimica et Cosmochimica Acta 72, 780-792.

Vigier, N., Gislason, S.R., Burton, K.W., Millot, R., Mokadem, F. (2009) The relationship between riverine lithium isotope composition and silicate weathering rates in Iceland. Earth and Planetary Science Letters 287, 434-441.

WALKER, JC G, HAYS, PB, KASTING, J.F. (1981) A negative feedback mechanism for the longterm stabilization of Earth's surface temperature. Journal of Geophysical Research 86, 9776-9782. 